\title{
Drug Treatment Versus Surgical Treatment for Tubal Ectopic Pregnancy: an Integrative Review

\begin{abstract}
Amanda Thaysa de Oliveira Cruz ${ }^{1}$, Samara Dourado Matos ${ }^{1}$, Maria do Carmo Andrade Duarte de Farias ${ }^{2}$, Kamila Nethielly Souza Leite ${ }^{3}$, Anne Milane Formiga Bezerra ${ }^{4}$, Juliana de Almeida Leandro Bezerra ${ }^{5}$, Kévia Katiúcia Santos Bezerra ${ }^{6}$
\end{abstract}

\section{Abstract}

Objective: This study aims to compare characteristics of the clinical and surgical treatment of ectopic pregnancy in women suitable for both treatments.

Method: An integrative review, with retrospective data and quantitative approach, was carried out using the electronic database PubMed, a service of the U.S. National Library of Medicine, and Scientific Electronic Library Online (SciELO). To be included, studies needed to be published between the years 2005-2015, in national and international journals, be available in Portuguese, English or Spanish with full text access. The population consisted of 86 articles and 6 studies were extracted for the sample.

Results: Two articles were published in 2014, while only 1 article was published each year in 2006, 2008, 2010 and 2012. There were no articles in Portuguese and most were in English.

Conclusion: Restriction studies published in Brazil make scientific evidence less applicable to clinical practice in public health.

\section{Introduction}

Among frequent pathologies for gynaecology service and causes of disease in women of reproductive age, ectopic pregnancy has shown increasing incidence and considerable levels of morbidity and mortality in the first trimester of pregnancy $[1,2]$. Fortunately, with early
1 Doctor of Primary Care in Petrolina/PE, formed by UFCG Campus Cajazeiras.

2 Academic Unit of Life Sciences, Teacher Training Center, Federal University of Campina Grande. Cajazeiras, Paraíba, Brazil.

3 Nurse. Master in Nursing at the Federal University of Paraiba, Bachelor Professor of Nursing course at FIP, PB, Brazil.

4 Nurse Professor of Patos Integrated College, FIP, PB, Brazil.

5 Nurse graduated from Patos Integrated College, FIP, PB, Brazil.

6 Gynecologist and Obstetrician, assistant professor of UFCG and Assistance Medical Director at HUJB-UFCG.

\section{Contact information:}

Kévia Katiúcia Santos Bezerra.

Address: R. Cel Candid de Assis, 375.

Sala 4 Centro, Pombal/PB.

CEP: $58840-000$.

Tel: $+55(83) 996184000$

" keviabezerra@gmail.com

Keywords

Ectopic pregnancy; Public health; Clinical Treatment. 
diagnosis and proper clinical management, there is increased incidence of favourable outcomes. In the US, the number of patients diagnosed with ectopic pregnancy increased from 17,800 in 1970 to 108,800 cases in 1992, representing $2 \%$ of pregnancies in that country [3].

This increased incidence is a reflection of the improvement of non-invasive diagnostic methods, thus allowing for early diagnosis of ectopic pregnancy [4]. Ectopic pregnancy is defined as pregnancy which occurs outside the uterine cavity. In $97 \%$ of cases, it is located in the oviduct and, of these, approximately $55 \%$ occur in the bulb region, $25 \%$ in the isthmus, $17 \%$ in the fimbria and $3 \%$ into the abdominal cavity, ovary and cervix [5]. There is also unknown place of pregnancy (UPP), when the site of implantation is not identified immediately by imaging methods [6]. The patient with ectopic pregnancy can present signs and mild symptoms, including abnormal uterine bleeding, pain in the lower abdomen (from insidious pain to acute pain), gastrointestinal disorders, to hypovolemic shock with hemodynamic instability and need for emergency surgical treatment [7].

Diagnosis is conducted by transvaginal sonography and serial measurements of $\beta$-hCG hormone. If associated with $\beta$-hCG dosages suggestive of pregnancy and sonographic findings are negative, we have the diagnosis of UPP, which will become evident with the evolution of the framework, and may be an intrauterine pregnancy, ectopic pregnancy or a persistent gestation of unknown place [8].

The treatment is guided by hemodynamic stability of the patient, her levels of $\beta-h C G$, and eligibility criteria for therapeutic options. The treatment options include surgery (laparoscopy or open surgery), drug treatment with methotrexate or expectant treatment [9].

The postponement of the diagnosis can have devastating consequences to the lives of patients in fertile and productive age, factors that justify the choice of the subject $[2,10]$. For these reasons, the present study aims to compare the clinical and surgical treatment of ectopic pregnancy in patients who meet the eligibility criteria for the two treatment options, and thus, identify the advantages and disadvantages of each method using an integrative review.

\section{Methods}

An integrative review study was developed with retrospective data and a quantitative approach. This study allows for the synthesis and analysis of the knowledge produced previously about the investigated theme to apply to clinical practice in order to facilitate the decision made and generate more effective care. We opted for an integrative review, because, among the methods used for evidencebased practice, it is the one that best fits the purpose of this work, as it allows for the inclusion of experimental and non-experimental studies, while also combining data from the theoretical and empirical literature, providing a broader understanding of the subject of interest [11].

Similar to other studies using evidence-based practice, the integrative review produces quality results, applicable in a reliable way to clinical practice; thus, the study needs to be developed according to rigorous methodology. Therefore, the steps must be followed to enable effective analysis and synthesis of scientific knowledge that has been produced on the subject to be studied. In preparing this report, we used the structure described by Botelho, Cunha and Macêdo [12].

The initial step was the question for developing the integrative review and guide for the remaining stages of the study. At that time, we identified the theme and the formulation of the guiding question [13]. Thus, in relation to the chosen topic, surgical and medical treatment of tubal ectopic pregnancy in women, the question raised was: What are the advantages and disadvantages of medical and surgical treatments in women who meet the eligibility criteria for the two treatment options? 
In the second stage, we defined the criteria for sample selection. The research was conducted using Published Medical - a service of the U.S. National Library of Medicine (PubMed) and Scientific Electronic Library Online (SciELO) databases. The keywords were: 'Ectopic pregnancy', 'tubal pregnancy', 'methotrexate', 'laparoscopy', 'open surgery'. The inclusion criteria used to limit the articles were: free access to full text; published within a period of 10 years (2005 to 2015); written in Portuguese, English or Spanish; sample of premenopausal women; have been designed in order to obtain results with relevant evidence levels (I, II, III, IV and $\mathrm{V})$. Exclusion criteria were based on the need to collect information pertinent to the research question; thus, articles that did not have free full text access, published in journals more than 10 years ago and articles that used animals and not humans were not included.

The investigation of the articles was conducted on 12 September 2015. The searches were conducted as follows: ectopic pregnancy and clinical treatment and surgery (Search I) and then, ectopic pregnancy and methotrexate and laparoscopic and open surgery (Search II). Thus, in the first search we found 1087 articles and 11 articles in Search II. After the inclusion of the filters, 82 articles in Search I and 1 article in Search II were found. Using the SciELO database, 4 articles were found for Search I, and 2 articles for Search II. After the inclusion of the filters, 2 articles in Search I and 1 article in Search II were found. Thus, a total of 86 articles were found in PubMed and SciELO.

The third step included a detailed reading of the titles, keywords and abstracts of all publications found based on the inclusion and exclusion criteria. Full reading was conducted of the selected articles to ensure they fulfilled the purpose of the study. This analysis step resulted in a total of 6 items, with 1 from the SciELO database and 5 from PubMed.

The fourth stage entailed a compendium and documentation of data and information contained in the selected articles. For this, we used a popular tool in health sciences for extraction and organisation of data. The method included a synthesis matrix which is used to protect the researcher from possible errors during the analysis [11]. The categories analysed were: identification, institution of study, type of publication, objective of the research, sample, interventions made, results, analysis, implications, level of evidence.

The analysis and interpretation of results occurred in the fifth stage, in which the selected texts were analysed and discussed in order to extract the knowledge needed for developing the work. In addition, gaps in knowledge were raised and proposals for future scientific papers were suggested. In the sixth stage, we presented the synthesis of knowledge, which involved the construction of scientific material from the evaluation of the results and conclusions drawn from selected articles. The formulation of the document allows the reader to assess the veracity of the procedures used in conducting this review.

\section{Results}

To better understand the study, the results are initially presented to demonstrate the characterisation of the six selected articles. Table 1 shows the distribution of articles according to the authors, year of publication, article title, journal, study type and level of evidence. These articles were all published in the databases PubMed and SciELO between the years 2005-2015; one article was published each year in 2006, 2008, 2010 and 2012 while two articles were published in 2014.

Table 2 summarises the results found when comparing the clinical and surgical treatment of ectopic pregnancy in women suitable for both treatments. The purpose of the questioning is to compare two models of treatment for the same disease process, seeking to demonstrate the most cost-effective and better immediate and future results. The first conclusion was the success rate of treatment, followed by observation of the significant cost of 
Table 1. Specifics on the articles analysed: authors, article title, journal, research type and level of evidence.

\begin{tabular}{|c|c|c|c|c|c|c|}
\hline Authors & Year & Title of the article & journal & Goal & $\begin{array}{l}\text { Kind of } \\
\text { study }\end{array}$ & $\begin{array}{l}\text { Level of } \\
\text { Evidence }\end{array}$ \\
\hline $\begin{array}{l}\text { Royal College of } \\
\text { Obstetricians and } \\
\text { Gynaecologists, } \\
\text { produced }\end{array}$ & $\begin{array}{c}19997 \\
\text { (revised 2010) }\end{array}$ & $\begin{array}{l}\text { The management of tubal } \\
\text { pregnancy }\end{array}$ & $\begin{array}{l}\text { Royal College of } \\
\text { Obstetricians and } \\
\text { Gynaecologists }\end{array}$ & $\begin{array}{l}\text { Discuss the therapeutic possibilities after the } \\
\text { diagnosis of tubal ectopic pregnancy }\end{array}$ & $\begin{array}{l}\text { Retrospective } \\
\text { cohort }\end{array}$ & 3 \\
\hline $\begin{array}{l}\text { Royal College of } \\
\text { Obstetricians and } \\
\text { Gynaecologists }\end{array}$ & $\begin{array}{l}2012 \\
\text { Guideline development group } \\
\text { membership and National } \\
\text { Collaborating Centre for } \\
\text { Women's and Children's } \\
\text { Health. }\end{array}$ & $\begin{array}{l}\text { Ectopic pregnancy and } \\
\text { miscarriage: Diagnosis } \\
\text { and initial management } \\
\text { in early pregnancy of } \\
\text { ectopic pregnancy and } \\
\text { miscarriage }\end{array}$ & $\begin{array}{l}\text { Guideline development } \\
\text { group membership and } \\
\text { National Collaborating } \\
\text { Centre for Women's and } \\
\text { Children's Health }\end{array}$ & $\begin{array}{l}\text { To assess the evidence for the efficacy and } \\
\text { safety of surgical and medical treatment of } \\
\text { tubal ectopic pregnancy in view of the success } \\
\text { of the primary treatment, tubal preservation } \\
\text { and future fertility. }\end{array}$ & $\begin{array}{l}\text { Retrospective } \\
\text { cohort }\end{array}$ & 3 \\
\hline Mol et al. & 2008 & $\begin{array}{l}\text { Current evidence } \\
\text { on surgery, systemic } \\
\text { methotrexate and } \\
\text { expectant management } \\
\text { in the treatment of tubal } \\
\text { ectopic pregnancy: a } \\
\text { systematic review and } \\
\text { meta-analysis }\end{array}$ & $\begin{array}{l}\text { Human Reproduction } \\
\text { Update. }\end{array}$ & $\begin{array}{l}\text { To evaluate the efficacy of surgery, drug } \\
\text { treatment and expectant management of } \\
\text { tubal ectopic pregnancy in terms of treatment } \\
\text { success (i.e., complete elimination of the } \\
\text { trophoblast tissue), taking into account } \\
\text { financial cost and future fertility. }\end{array}$ & $\begin{array}{l}\text { Systematic } \\
\text { review and } \\
\text { meta-analysis }\end{array}$ & 1 \\
\hline Silva & 2014 & $\begin{array}{l}\text { Pronóstico reproductivo } \\
\text { posterior a um embarazo } \\
\text { ectópico según modalidad } \\
\text { de tratamiento }\end{array}$ & $\begin{array}{l}\text { Revista Chilena de } \\
\text { Ginecologia e Obstetricia. }\end{array}$ & $\begin{array}{l}\text { Compare fertility rates in women with ectopic } \\
\text { pregnancy and without access to assisted } \\
\text { fertilisation techniques undergoing medical } \\
\text { treatment with methotrexate or surgical } \\
\text { treatment. }\end{array}$ & $\begin{array}{l}\text { Retrospective } \\
\text { cohort }\end{array}$ & 3 \\
\hline Elito Junior et al. & 2006 & $\begin{array}{l}\text { Tubal patency following } \\
\text { surgical and clinical } \\
\text { treatment of ectopic } \\
\text { pregnancy }\end{array}$ & Sao Paulo Medical Journal. & $\begin{array}{l}\text { Compare fertility rates in women with ectopic } \\
\text { pregnancy and without access to assisted } \\
\text { fertilisation techniques undergoing medical } \\
\text { treatment with methotrexate or surgical } \\
\text { treatment. }\end{array}$ & $\begin{array}{l}\text { Retrospective } \\
\text { cohort }\end{array}$ & 3 \\
\hline
\end{tabular}


Table 2. Success rate, cost and recurrence rate of ectopic pregnancy comparing surgical and medical treatment in ectopic pregnancy.

\begin{tabular}{|c|c|c|c|c|}
\hline Article & Year & Success rate & Costs & Recurrence rate \\
\hline Mol et al. & 2008 & $\begin{array}{l}\text { Treatment with methotrexate in multiple dose regimen } \\
\text { compared to laparoscopic salpingostomy: non-significant } \\
\text { trend towards greater success of systemic treatment with } \\
\text { methotrexate; treatment with systemic methotrexate } \\
\text { in a single dose with laparoscopic salpingostomy: } \\
\text { Laparoscopic salpingostomy had greater therapeutic } \\
\text { success. }\end{array}$ & $\begin{array}{l}\text { Systemic treatment with systemic } \\
\text { methotrexate in multi-dose was } \\
\text { significantly more expensive } \\
\text { than treatment by laparoscopic } \\
\text { salpingostomy; treatment with } \\
\text { systemic methotrexate in a single } \\
\text { dose showed significantly lower } \\
\text { cost compared to laparoscopical } \\
\text { surgical approach. }\end{array}$ & No recurrence rate \\
\hline Silva et al. & 2014 & $\begin{array}{l}\text { Therapeutic success rate with methotrexate }(72.6 \%) \\
\text { was less than the therapeutic success with surgery } \\
\text { (83.6\%), which is the salpingectomy (via open surgery or } \\
\text { laparoscopic surgery). }\end{array}$ & & $\begin{array}{l}\text { Ectopic pregnancy recurrence rate was } 9.4 \% \text { for } \\
\text { surgically treated group and } 12.3 \% \text { for the group } \\
\text { treated clinically }\end{array}$ \\
\hline $\begin{array}{l}\text { Royal College of } \\
\text { Obstetricians and } \\
\text { Gynaecologists, } \\
\text { produced }\end{array}$ & $\begin{array}{l}1999 \\
\text { (revised } \\
\text { 2010) }\end{array}$ & & $\begin{array}{l}\text { The direct costs for medical } \\
\text { treatment are significantly lower } \\
\text { than the costs of laparoscopic } \\
\text { surgery. }\end{array}$ & \\
\hline $\begin{array}{l}\text { Ectopic pregnancy } \\
\text { and miscarriage: } \\
\text { Diagnosis and initial } \\
\text { management in } \\
\text { early pregnancy of } \\
\text { ectopic, produced } \\
\text { by Royal College of } \\
\text { Obstetricians and } \\
\text { Gynaecologists }\end{array}$ & 2012 & $\begin{array}{l}\text { No statistically significant difference in the success rate in } \\
\text { women who received surgical treatment ( } 87 \%) \text { compared } \\
\text { to women who received clinical treatment }(79.3 \%) \text {. }\end{array}$ & $\begin{array}{l}\text { Methotrexate is the least expensive } \\
\text { option at } € 1432 \text {, followed by } \\
\text { laparoscopic ligation } £ 1608 \text {. } \\
\text { Laparoscopic Salpingostomy } \\
\text { proved to be the most expensive } \\
\text { option. }\end{array}$ & $\begin{array}{l}\text { No statistically significant difference in the recurrence } \\
\text { rate of ectopic pregnancy in women who received } \\
\text { surgical treatment }(6.5 \%) \text { compared to women } \\
\text { who received medical treatment with systemic } \\
\text { methotrexate (3.5\%); in another study, the recurrence } \\
\text { rate in the surgical treatment was } 5.3 \% \text { and in } \\
\text { medical treatment with local methotrexate was } 0 \% \text {. } \\
\text { Another study showed recurrence rate in the surgical } \\
\text { treatment of } 5.3 \% \text { compared to women who received } \\
\text { treatment with local methotrexate of } 0 \% \text {. }\end{array}$ \\
\hline
\end{tabular}

Source: PubMed and SciELO databases, 2005-2015. 
each treatment and, subsequently, the analysis of the recurrence of ectopic pregnancy after medical or surgical treatment.

Another approach that can be used to analyse the clinical and surgical treatment of ectopic preg- nancy is comparing the future fertility of the women as depicted in Table 3, as well as the quality of life of these women after treatment.

Table 3. Fertility and quality of life between surgical and clinical treatment in ectopic pregnancy.

\begin{tabular}{|c|c|c|c|}
\hline Article & Year & Fertility & Quality of life after treatment \\
\hline Mol et al. & 2008 & $\begin{array}{l}\text { Compared medical treatment with methotrexate and } \\
\text { surgery with laparoscopic salpingostomy; there was } \\
\text { no significant difference in the number of intrauterine } \\
\text { pregnancies between the groups, independent of the } \\
\text { methotrexate dosage. }\end{array}$ & \\
\hline Silva et al. & 2014 & $\begin{array}{l}\text { The pregnancy rate for surgical resolution group } \\
\text { was } 83.6 \% \text { and for the medical treatment with } \\
\text { methotrexate group was } 72.3 \% \text {, with no statistically } \\
\text { significant difference between groups. The pregnancy } \\
\text { resulted in live birth in } 82.2 \% \text { of women with surgical } \\
\text { treatment and } 72.3 \% \text { of those receiving medical } \\
\text { treatment. }\end{array}$ & \\
\hline $\begin{array}{l}\text { Elito Junior et } \\
\text { al. }\end{array}$ & 2006 & $\begin{array}{l}\text { Analysed the tubal patency by HSG, in patients } \\
\text { treated for ectopic pregnancy. The HSG findings of } \\
\text { ipsilateral tube showed that } 84 \% \text { (MTX) of them were } \\
\text { open. The contralateral tubal patency was } 97 \% \text { (MTX) } \\
\text { and } 83 \% \text { (salpingectomy), the obstruction of the } \\
\text { ipsilateral tube occurred in } 16 \% \text { of the MTX group. } \\
\text { Obstruction of the contralateral tube occurred in 3\% } \\
\text { of cases of MTX and in 17\% of cases with surgical } \\
\text { treatment. }\end{array}$ & \\
\hline Hill et al. & 2014 & $\begin{array}{l}\text { Reviewed fertility through the basement of the antral } \\
\text { follicle count (AFC), (FSH) the follicle stimulating } \\
\text { hormone levels (FSH) in serum, yield of oocytes, } \\
\text { subsequent clinical pregnancy and subsequent live } \\
\text { birth. There were no significant differences between } \\
\text { methotrexate and surgical groups in FSH, AFC, and } \\
\text { yield of oocytes in pre- and post-treatment values. } \\
\text { Clinical pregnancy and live births in breeding cycles } \\
\text { after treatment were similar between the two } \\
\text { treatment groups }\end{array}$ & \\
\hline $\begin{array}{l}\text { Royal } \\
\text { College of } \\
\text { Obstetricians } \\
\text { and } \\
\text { Gynaecologists } \\
\text { (Article 6), }\end{array}$ & 2012 & $\begin{array}{l}\text { There was no statistically significant difference in the } \\
\text { future pregnancy rate between women who received } \\
\text { surgical treatment } 48 / 92(52.2 \%) \text { compared with } \\
\text { women who had received medical treatment with } \\
\text { systemic methotrexate, } 50 / 86 \text { (58.1\%). By analysing } \\
\text { tubal preservation there was also no statistically } \\
\text { significant difference between the two types of } \\
\text { treatment. The ipsilateral tubal patency was also } \\
\text { similar between groups. }\end{array}$ & $\begin{array}{l}\text { The occurrence of pain and depression in } \\
\text { women who received clinical or surgical } \\
\text { treatment for ectopic pregnancy was } \\
\text { similar, though quality of life after two } \\
\text { days and after two weeks was lower in } \\
\text { those who received surgical treatment, } \\
\text { but after } 16 \text { weeks the overall quality of } \\
\text { life was the same for both groups. }\end{array}$ \\
\hline
\end{tabular}

Source: PubMed and SciELO databases, 2005-2015. 


\section{Discussion}

In all studies analysed in Table 1, the purpose was to compare the clinical treatment with methotrexate and surgical treatment for ectopic pregnancy, with different approaches. With regard to clinical treatment, the single dose protocol were used, multiple doses, and local applications, since the surgical treatment alternated between open and laparoscopic means, and surgical techniques were salpingectomy and salpingostomy. Regarding the language, English predominated, followed by Spanish while no articles were published in Portuguese.

Regarding the designs of the studies, one publication had a low level of scientific evidence, which was a descriptive study. However, most research had a good level of scientific evidence, such as the cohort study (4 articles) and meta-analysis (1 article). Journals that published the articles were: Royal College of Obstetricians and Gynaecologists; Guideline development group membership and National Collaborating Centre for Women's and Children's Health; Human Reproduction Update; Rev Chilena of Obstetrics and Gynecology; Sao Paulo Medical Journal; Fertil Steril (1 article in each journal).

Table 2 shows the cost-effectiveness and better immediate result for each treatment chosen for a better resolution of ectopic pregnancy. The first conclusion was the success rate of treatment. In the work by Mol, 15 randomised clinical trials with patients with ectopic pregnancy, hemodynamically stable and with no contraindications for methotrexate use were analysed [7]. Among the analysed studies, five trials were conducted in the US, two in Egypt and France and the others in Finland, Iran, New Zealand, Sweden, Netherlands and the United Kingdom. Comparing systemic methotrexate treatment in multiple dose regimen and laparoscopic salpingostomy, a multicentre study found a nonsignificant trend toward greater success of drug treatment [14].

In the same study, a comparison of treatment with systemic methotrexate in a single dose with laparoscopic salpingostomy, the combined results of the four tests analysed involving 265 hemodynamically stable women with an EP small tubal full, showed that a single dose of methotrexate systemic was significantly less successful than laparoscopic salpingostomy [20, 23, 24].

A retrospective cohort study, conducted among 219 patients with a diagnosis of ectopic pregnancy in Padre Hurtado Hospital, between the months of January 2002 and December 2007, found successful treatment with methotrexate use in $72.6 \%$ of patients submitted to clinical treatment, requiring surgical approach in 18 (27.4\%) cases. Of the 193 cases analysed, 128 patients underwent surgical treatment, the salpingectomy (open or laparoscopic) with a success rate of $83.6 \%$ [15].

The NICE Clinical Guideline [16] was performed to compare medical and surgical treatment of ectopic pregnancy in ten studies $[17,18,19,20,14,21$, $22,23,24,25]$. All included studies were randomised: three were conducted in the Netherlands [14, 18, 22], two in France $[19,20]$, one in Denmark [21], one in the US [23], one in Israel [25], one in New Zealand [24] and one in Italy [17]. Regarding the success rate, a five-study meta-analysis found no statistically significant difference in the success rate in women who received surgical treatment (87\%) compared to women who received medical treatment with methotrexate $(79.3 \%)[14,20,21$, 23, 24].

The second conclusion concerns the costs. In Mol's work [7], comparing systemic methotrexate in multiple dose regimen and laparoscopic salpingostomy, a multicentre study found that treatment with multi-dose systemic methotrexate was significantly more expensive than treatment by laparoscopic salpingostomy [26]. The average total cost per patient was $€ 4,207$ (direct costs $€ 2,426$; indirect costs $€ 1,781$ ) for clinical treatment and $€ 2,990$ (direct costs $€ 1,853$; indirect costs $€ 1,137)$ for treatment with laparoscopic salpingostomy with a difference of $€ 1,217$ (95\% Cl 666-1775). However, the use of 
a confirmatory laparoscopy in women who received clinical treatment has been used, whereas in clinical practice this is not standard. Comparing treatment with systemic single dose methotrexate with laparoscopic salpingostomy, the combined results of the four trials involving 265 hemodynamically stable women with an EP small tubal full, showed that the treatment with systemic single dose methotrexate showed significantly lower cost compared to laparoscopic surgical approach: direct average cost per patient was $756 €$ and $1,585 €$, respectively, with a mean difference of $€ 829$ (95\% Cl 599-1060) [20, 23, 24].

In 'The management of tubal pregnancy', a cost comparison was made between the medical and surgical treatment of ectopic pregnancy through randomised clinical trials which showed that the direct costs of medical treatment were significantly lower than the costs of laparoscopic surgery. However, in both randomised clinical trials, no cost savings was seen in the serum $\beta-h C G$, levels above 1 , $500 \mathrm{U} / \mathrm{l}$, due to the increased need for continued treatment and prolonged follow-up [16].

In 'Ectopic pregnancy and miscarriage: Diagnosis and initial management in early pregnancy of ectopic', a comparison of the costs associated with three treatment strategies (2 surgical and 1 clinic): laparoscopic salpingostomy, laparoscopic salpingectomy and use of methotrexate, found that methotrexate was the least expensive option at 1,432 $€$, followed by laparoscopic ligation 1,608 f. The laparoscopic salpingostomy proved to be the most expensive option [16].

The third issue of importance was GE recurrence after medical or surgical treatment. In a retrospective cohort study, conducted in 219 patients with a diagnosis of ectopic pregnancy, the ectopic pregnancy recurrence rate was $9.4 \%$ for the surgically treated group and $12.3 \%$ for the group treated medically with methotrexate [15].

In 'Ectopic pregnancy and miscarriage: Diagnosis and initial management in early pregnancy of ectopic', a meta-analysis of two studies found no statistically significant difference in the recurrence rate of ectopic pregnancy in women who received surgical treatment (6.5\%) compared with women who had received medical treatment with systemic methotrexate $(3.5 \%)[18,21]$. In the same scientific work, another meta-analysis of two studies did not demonstrate a statistically significant difference in the recurrence rate of ectopic pregnancy in women who received surgical treatment (5.3\%) compared with women who received medical treatment with methotrexate location (0\%) [20, 25].

In the same work, a study showed no statistically significant difference in the recurrence of ectopic pregnancy in women who received surgical treatment (5.2\%) compared to women who received medical treatment with systemic or local methotrexate (2\%) [20].

Another variable that can be used to compare the clinical and surgical treatment of ectopic pregnancy is the future fertility of women. In Mol's article, searching randomised studies, comparing the clinical treatment with multiple doses of methotrexate and surgery with laparoscopic salpingostomy for ectopic pregnancy, revealed in a multicentre study Pereira were treated 100 women hemodynamically stable, with future fertility was assessed in 74, there was no significant difference in the number of intrauterine pregnancies between groups [7, 18].

Since taking into account the treatment with a single dose of MTX, compared to laparoscopic salpingostomy, were found as 4 the results of the four combinations involving 265 women, of which the future fertility was analyzed at 98 , there were no significant differences between the number of intrauterine pregnancies. Therefore, considering the results published by Mol, there was no significant statistical difference between women treated with MTX and those who received surgical treatment with respect to future fertility, as identified by intrauterine pregnancy, regardless of methotrexate regimen $[7,20,23,24]$. 
In the study of women treated for ectopic pregnancy in a hospital of reference, 288 patients were diagnosed in the period, of which 193 cases were selected for analysis. 128 were patients undergoing surgical resolution, open or laparoscopic, and 65 patients were treated with methotrexate. In the analysis, the pregnancy rate for surgical resolution group was $83.6 \%$ (107 of 128 patients) and for the medical treatment with methotrexate group was $72.3 \%$ (47 of 65 patients), with no statistically significant difference between groups. Of the women studied, pregnancy resulted in live birth in $82.2 \%$ of women with surgical treatment and $72.3 \%$ of the rest receiving medical treatment [15].

Another study examined the possibility of future fertility for women treated for ectopic pregnancy in the obstetrics department of the Federal University of São Paulo, in the period 1994-2002, by performing hysterosalpingography (HSG), and thus predicting the chances of future pregnancy of these women through the study of tubal patency, since fertility can be evaluated indirectly through HSG and directly by pregnancy. 115 women were treated for ectopic pregnancy, divided into three groups: 30 treated with a single dose of methotrexate (MTX), 50 with expectant management and 35 with salpingectomy [27]. The HSG findings of tubaipsilateral showed that 84\% (MTX) and 78\% (expectant management) of patients' tubes were open. The contralateral tubal patency was 97\% (MTX), 92\% (expectation management) and 83\% (salpingectomy); obstruction of the ipsilateral tube occurred in $16 \%$ of the MTX group and $22 \%$ of the expectant management group.

Obstruction of the contralateral tube occurred in $3 \%$ of MTX cases and in $8 \%$ of expectant management cases. In the group undergoing surgery (salpingectomy), contralateral tubal obstruction occurred in $17 \%$ of cases. Obstruction of the contralateral tube was more frequent in the group that underwent surgery than in clinical treatment groups. According to the author, the explanation for these results is that, most likely, surgery may lead to more adhesions because of the peritoneal factor, resulting in infertility. However, in the study, there was no significant difference between the groups in relation to the contralateral tubal patency. Although the observed difference did not reach the usual level of significance, the data seem to favour clinical treatment, however, further studies are need to confirm the trend [27].

Regarding future fertility, a study of patients treated for ectopic pregnancy at the assisted reproduction clinic Shady Grove Fertility in 2004-2010, analysed the baseline count of folículosantrais (AFC), the follicle stimulating hormone levels (FSH) in serum, yield of oocytes, subsequent clinical pregnancy and subsequent live birth. In the sample, 153 patients were treated with methotrexate and 36 patients were treated with surgery for ectopic pregnancy or pregnancy of unknown location [28]. Patients with combined methotrexate therapy and surgical treatment $(n=27)$ were excluded from the primary analysis, but were included in a sub-analysis. Neither the methotrexate group or surgery demonstrated abnormalities in ovarian reserve after treatment. Methotrexate group had baseline FSH values of 6.9 (2.4 to 14.2) before and 7.2 (2.3 to 16.3) after treatment, the AFC values of 12 (1-53) before and 13 (1-60) after treatment, oocyte yield of 14 (2-36) before and 14 (0-35) after treatment.

The surgery group had FSH baseline values of 7.3 (2.6 to 16.0) before and 7.9 (5.1 to 10.4) after treatment, AFC values of 10 (3-50) before and 10 (4-45) after treatment and, oocyte yield of 13 (3-31) before and 12 (3-31) after treatment. There were no significant differences between methotrexate and surgical groups in FSH, AFC, and yield oocytes in pre- and post-treatment. Clinical pregnancy and live births in breeding cycles after treatment were similar between the two treatment groups.

The study of Clinical Guideline analysed various publications [16]; a meta-analysis of two studies found no statistically significant difference in future 
pregnancy rate among women who received surgical treatment 48/92 (52.2\%), compared to women who received medical treatment with systemic methotrexate 50/86 (58.1\%) [18, 21]. By analysing the tubal preservation, we did not find a statistically significant difference in the preservation of the fallopian tubes in women who received salpingostomy $45 / 49$ (91.8\%) compared to women who received medical treatment with systemic methotrexate 46/51 (90.2\%) MTX [14]. The same study also examined the ipsilateral tubal patency, showing $23 / 39$ (59\%) of patent ipsilateral tubes in women who received surgical treatment and 23/42 (54.8\%) for women who received medical treatment with systemic methotrexate.

The future fertility of the patient treated for ectopic pregnancy, whether surgical or medical treatment, was also analysed, and verified that there was no statistically significant difference in future pregnancy rate of patients.

Another variable that can be analysed, in considering treatment for ectopic pregnancy, is quality of life of post-treatment women. In the studies analysed by Clinical Guideline, no significant statistical differences in pain and depression were shown by women who received medical or surgical treatment, however the quality of life after 2 days and after two weeks was lower in those who received surgical treatment, and after 16 weeks the overall quality of life was the same for both groups [16, 22].

\section{Conclusions}

Ectopic pregnancy, implantation and development of the zygote outside the uterine cavity, is one of the main causes of maternal mortality in the first trimester. The patient with ectopic pregnancy can present with atypical symptoms from vague (abnormal uterine bleeding, abdominal pain, gastrointestinal symptoms) to hypovolemic shock by tubal rupture and immediate need for surgical intervention with risk of death for the patient.
With the advent of serum evaluation of beta fraction of chorionic gonadotropin hormone ( $\beta-h C G$ ) and transvaginal ultrasonography, early diagnosis of ectopic pregnancy has become more frequent, reducing invasive interventions, enabling drug clinical treatment and, in selected situations, expectant management. Depending on the hemodynamic stability and serum $\beta$-hCG levels, treatment options are surgery (salpingostomy by open or laparoscopic), drug treatment with the antimetabolite methotrexate (which can be administered systemically and/or locally) and expectant conduit with constant monitoring and follow-up.

For a greater range of therapeutic possibilities, the participation of ectopic pregnancy carrier women in decision-making has become reality, if necessary, therefore, the analysis along with the patient's treatment more effective, safe and less immediate and future consequences for all. In order to compare the surgical and medical treatment in women meeting the eligibility criteria for both treatments, we analysed scientific studies with strong levels of evidence and determined the results with the greatest impact.

Evaluating the success rate of both treatments, two articles showed the success rate was higher in the surgical treatment, when compared to drug treatment; one of them showed no significant trend towards greater success in the clinical treatment and another showed no statistically significant difference in the success rate. Regarding with the costs associated with the handling of ectopic pregnancy, three studies found that the least expensive option is the use of methotrexate. One study found that multidose treatment with methotrexate is more expensive than the laparoscopic surgical option.

The evaluation of ectopic pregnancy recurrence rate, in two of the studies analysed, showed a slight difference, with the surgically treated group having a lower recurrence rate than the group treated clinically. 
The future fertility of the patient treated for ectopic pregnancy, whether surgical or medical treatment was also analysed, and verified that there was no statistically significant difference in future pregnancy rate of patients.

As for the quality of life of women who received medical or surgical treatment, one study found that pain and depression were similar in both treatments. The overall quality of life after 2 weeks of treatment was lower in those patients undergoing surgical approach, but after 16 weeks both groups had similar quality of life scores.

6 scientific publications were included in this review, including 1 meta-analysis and systematic review, four studies with retrospective cohort design and 1 descriptive study, with strong levels of evidence. This review highlights the importance of the subject matter and presents evidence about the comparison of outcomes in clinical and surgical treatment of ectopic pregnancy in selected women, which can inform clinical practice.

\section{References}

1. Fernandez M, Pauthier S, Doumerc S, Lelaidier C Olivennes $F$, Ville $Y$, et al. Ultrasound-guided injection of methotrexate versus laparoscopic salpingotomy in ectopic pregnancy. Fertil Steril. 1995; 63 (1): 25-29.

2. Brito MB, Silva JCR, Barbosa HF, Neto OBP, FJC, Reis Silva ACJSR, et al. clinical treatment of ectopic pregnancy with metotrexato. Femina. 2009; 37 (1): 29-34.

3. Bittar RE, Pereira PP, Liao AW. obstetrical complications. Zugaib obstetrics. Sao Paulo: Manole.2008; 2: 550-551.

4. Atri M, Leduc C, Gillett P, Bret PM, Reinhold C, Kintzen G, et al. Role of transvaginal sonography in the diagnosis and management of ectopic pregnancy. Radiographics. 1996; 16 (4): 755-74.

5. Samith IC, Perales I, Romero G. Clinical epidemiological y Análisis del embarazo Ectopic: Los Angeles Base Hospital. Rev Obstet Gynecol chil. 2010; 75 (2): 96-100.

6. Kirk And The Daemen, Papageorghiou AT, Bottomley C, Condous G, De Moor B, et al. Why are some ectopic Characterized Pregnancies Pregnancies of the unknown location at the initial transvaginal ultrasound examination? Acta Obstet Gynecol Scand. 2008; 87 (11): 1150-1154.
7. Mol F, Mol BW, Ankum WM, Van der Veen F, Hajenius PJ, et al. Current evidence on surgery, systemic methotrexate and expectant management in the treatment of tubal ectopic pregnancy: a systematic review and meta-analysis. Hum Reprod Update. 2008; 14 (4): 309-319.

8. Kurt MDBs, Norah M, Van Mello, Tom Bourne FRCOG, Emma K, Ben VC, et al. Pregnancy of unknown location: a consensus statement of nomenclature, definitions, and outcome. Fertil steril. 2011; 95 (3): 857-866.

9. National collaborating center for women's and children's health et al. Ectopic pregnancy and miscarriage: diagnosis and initial management in early pregnancy of ectopic pregnancy and miscarriage. 2012.

10. Farias-Son AF, Oliveira JS, Melo KA, Gomes AN, Leite MS. Methotrexate in treatment of ectopic pregnancy: a retrospective analysis of risks in therapeutic protocol. Rev Bras Farm Hosp Serv Health São Paulo. 2014; 5 (1): 48-53.

11. Souza MT, Silva MD, Carvalho R. Integrative review: what is it and how to do. Einstein. 2010; 8 (1): 102-106.

12. Botelho LLR, Cunha CCA, Macedo M. The method of integrative review in organizational studies. Management and Corporation. 2011; 5 (11): 121-136.

13. Mendes KDS, Silveira RCCP, Galvão CM. Integrative review: a research method to incorporate evidence in health and nursing. Text and Context Nursing. 2008; 17 (4): 758.

14. Hajenius PJ, Engelsbel S, Mol BW, Van der Veen F, Ankum WM, Bossuyt PM, et al. Randomised trial of systemic methotrexate versus laparoscopic tubal salpingostomy in pregnancy. Lancet. 1997; 350 (9080): 774-779.

15. Silva GMC, Errázuriz VJ Urzúa VMJ, Sumar UF, Troncoso RF Rondini FDC, et al. Pronóstico reproductivo posterior a un embarazo Ectopico según modalidad de tratamiento. Rev chilobstet Gynecol. 2014; 79 (4): 262-268.

16. Gudeline C. Medical management of ectopic pregnancy. Guidelines relevant to gynecology. 2012; 2-8.

17. Colacurci N, R Zarcone of Franciscis P, Mele D, Mollo A, Placido G. Tubal patency after laparoscopic treatment of ectopic medical pregnancy. Panminerva. 1998; 40 (1): 45-47.

18. Pereira GD, Hajenius PJ, Mol BW, Ankum WM, Hemrika DJ, Bossuyt PM, et al. Fertility outcome after systemic methotrexate and laparoscopic salpingostomy for tubal pregnancy. Lancet. 1999; 353 (9154): 724-725.

19. Fernandez MR, Pauw RM, Clarke JM. Discoloration of wheat kernels by Pyrenophoratritici-repentis. Canadian Journal of Plant Pathology. 1998; 20 (4): 380-383.

20. Fernandes BUT, Moretti TBC, Olivotti BR. Epidemiological and clinical aspects of ectopic Pregnancies at a university service between 2000 and 2004. Rev Assoc Med Bras. 2007; 53 (3): 213-216.

21. Moeller LBK, Moeller C, Thomsen SG, Andersen LF, Lundvall $\mathrm{L}$, Kjer JJ, et al. Success and spontaneous pregnancy rates Following systemic methotrexate versus laparoscopic surgery for tubal Pregnancies: a randomized trial. Acta Obstet Gynecol Scand. 2009; 88 (12): 1331-1337. 
22. Nieuwkerk PT, Hajenius PJ, Van der Veen F, Ankum WM, Wijker W, Bossuyt PM, et al. Systemic methotrexate therapy versus Laparoscopic salpingostomy in tubal pregnancy. Part II. Patient preferences for systemic methotrexate. Fertil steril. 1998; 70 (3): 518-522.

23. Saraj AJ Wilcox JG, Najmabadi S, Stein SM, Johnson MB, Paulson RJ. Resolution of hormonal markers of ectopic gestation: a randomized trial comparing single-dose intramuscular methotrexate with salpingostomy. Obstetr Gynecol. 1998; 92 (6): 989-994.

24. Sowter MC, Farquhar CM, Petrie KJ, Gudex G. A randomized trial comparing single dose systemic methotrexate and laparoscopic surgery for the treatment of unruptured tubal pregnancy. BJOG: Journal Obstet Gynaecol. 2001; 108 (2): 192203.

25. Zilber U, Pansky T, Bukovcky MD, Golan M. Laparoscopic salpingostomy versus Laparoscopic site methotrexate injection in the management of unruptured ectopic gestation. Journal Obstet Gynecol. 1996; 175 (3): 600-602.

26. Mol BWJ, Patrick MMB, Petra JH, Willem MA, Fulco VVDV. Conservative versus radical surgery for tubal pregnancy. Acta Obstet Gynecol Scand. 1996; 75 (9): 866-867.

27. Elito JJ, Montenegro NAMM, Smith RC, Camano I. Ectopic pregnancy is no route-diagnosis and treatment. Current situation. See Obstet Gynecol. 2008; 30 (3): 149-159.

28. Hill MJ, Cooper JC, Levy G, Alford C, Richter KS, Cherney AH, et al. Ovarian reserve and subsequent ART outcomes Following methotrexate therapy for ectopic pregnancy and pregnancy of unknown location. Fertil steril. 2014; 101 (2): 413.
Publish in International Archives of Medicine

International Archives of Medicine is an open access journal publishing articles encompassing all aspects of medical science and clinical practice. IAM is considered a megajournal with independent sections on all areas of medicine. IAM is a really international journal with authors and board members from all around the world. The journal is widely indexed and classified Q1 in category Medicine. 